\section{Visión Electrónica \\ Más que un estado sólido}

http: revistas.udistrital.edu.co/ojs/index.php/visele/index

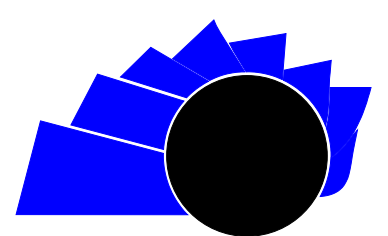

VISIÓN ELECTRÓNICA
UNIVERSIDAD DISTRITAL FRANCISCO JOSÉ DE CALDAS

A CASE-STUDY VISION

\title{
Radar and UAV: georeferencing and airspace surveillance system
}

\author{
Radar y UAV: sistema de georeferencia y vigilancia del espacio aereo
}

\author{
Jonnathan Navarro Roa. ${ }^{1}$, Félix Parca Acevedo. ${ }^{2}$, Giovani Mancilla Gaona. ${ }^{3}$
}

INFORMACIÓN DEL ARTÍCULO

\section{Historia del artículo:}

Enviado: 11/06/2017

Recibido: 24/07/2017

Aceptado: 02/08/2017

\section{Keywords:}

Drone

Detection

Radar

SAR

UAV

UAVSAR.

Open access

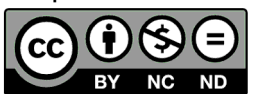

Palabras clave:

Drone

Detección

Radar

SAR

UAV

UAVVSAR

\section{ABSTRACT}

A "RADAR" system, from the English Acronym "Radio Detention and Ranging" . Better known as "Radio Detection and Location" RDL. It is a system for detecting and positioning objects through shipping and reflection of electromagnetic waves in terms of the time of issue and the return of the waves and their speed (calculated by the Doppler effect of the electromagnetic signal received). Meanwhile, an autonomous unmanned vehicle, also known as Unmanned Aerial Vehicle, UAV, which is defined as an aircraft which does not carry a human operator, and uses aerodynamic forces to provide airlift by itself. Therefore, it can fly autonomously or it can be operated by remote control. This article focuses on the review of experiences where these two technologies are integrated, particularly UAVSAR (Uninhabited Aerial Vehicle Synthetic Aperture Radar). This is done in order to support research concerning the combination thereof to be applied in georeferencing humanitarian missions or military missions that require monitoring of airspace.

\section{RESUMEN}

Un sistema RADAR -del acrónimo en inglés "Radio Detention and Ranging", es decir, "Detección y Localización por Radio", es un sistema de detección y posicionamiento de objetos a través de envío y reflexión de ondas electromagnéticas en términos del tiempo de emisión y regreso de las ondas así como de su velocidad calculada mediante el efecto Doppler de la señal electromagnética recibida. En tanto, un vehículo autónomo no tripulado -cuyo nombre oficial es Unmanned Aerial Vehicle (UAV), se define como un vehículo motorizado aéreo que no lleva un operador humano, y utiliza las fuerzas aerodinámicas para proporcionar la elevación del mismo: es decir, puede volar de forma autónoma o ser dirigido por control remoto. El presente artículo se centra en la revisión de experiencias donde se integran estas dos tecnologías -particularmente la UAVSAR (Vehículos aéreos no tripulados con sistema RADAR de apertura sintética)-, con el fin de soportar investigaciones referentes a la combinación de las mismas para ser aplicadas como herramienta de georreferenciación para misiones humanitarias y misiones militares que busquen vigilar el espacio aéreo. 


\section{Introduction}

Today, technological advances have allowed to polarize the use and development of innovative initiatives. Even though, the weapon industry has been responsible for the technological development of UAVs and radar systems RS, the combination of these two technologies have allowed them to be used in other areas such as: communication and coordination of operations, ground cover, people search and geo-referencing for land restitution in armed conflicts. However, there are only very few assignments that reflect a state of art of RS and UAV technologies with the purpose of supporting developments, innovations and research in this field.

This article is structured and encouraged by means of: First a brief state of the art is described about the origins in the combination of UAV with RS. Here, a mathematical and physical model on how the two technologies interact, followed by the details of the technical operation of UAVs and RS specified. Also, a description about some regulations and policies adopted for UAVs and RS, followed by the illustration of some applications in the field of humanitarian missions and military missions. And finally, the conclusions given.

\section{Methods and Materials.}

For the selection of the documentary sources of this exploratory research, there were chosen the following categories of analysis:

- State of the Art: It takes into account the beginning of UAVs and RS since the nineteenth century, passing through the twentieth century up to these current days (the twenty first century), in terms of chronological evolution on technological aspects.

Reference websites like MAXWELL AIR FORCE BASE and papers from agencies like Navy Papers as well as Documents were chosen

- Mathematics and Physics Model: Taking into account Geometrical parameters, stability observation and control under the model of Euler and Newton (for UAVs). For the RADAR, an approach was made by observing the Ka frequency bands and waves form FMCW Ka frequency and waves form $\mathrm{FMCW}^{4}$. Engineering journal references were chosen like Vision Electronics, websites such as IEEE Xplore and E-books like Artech House, Inc., Norwood, "Millimeter-wave radar targets and clutter".

- Functioning: This part takes into account the operation of UAVs with RADAR (UAVSAR), simulation of environments $\mathrm{SAR}^{5}$ in STRIPMAP 6 mode, point targets, widespread, UAV movement influence in SAR image formation and inertial systems and or navigation. Aviation journal references were chosen, for example: HISPAAVIACION, websites, IEEE Xplore and E-books like Radar Signals and Wiley-Interscience.

- Regulations and policies: Takes into account the regulations, of the $\mathrm{OACI}^{7}$, Civil Aeronautics of Colombia and ITU $^{8}$ recommendations. Website references were chosen from OACI and the ITU recommendations for the milimetric bands.

- Civil Applications: It has in mind the applications for natural disasters, to prevent and control fires, and georeference. There were references chosen from websites like,IEEE Xplore, Agustín Codazzi and E-Books like Resolution Requirements for Passive Sense \& Avoid, Alion Science \& Technology, and 3592 Collins Ferry Rd.

- Military Applications: It considers reconnaissance and surveillance applications, extraction maps, maritime control, meteorology and furtive penetration. There were references chosen from websites like IEEE Xplore, USAF papers and documents, and conferences from the International Conference on Sensor Technologies and Applications.

The methodology chosen was endorsed by the Research group GIDENUTAS ${ }^{9}$.

\section{Development:}

\subsection{State of the Art:}

Initially unmanned aviation had its beginnings in the nineteenth century with models manufactured by

${ }^{4}$ FMCW: Frequency Modulated Continuous Wave

${ }^{5}$ SAR: Synthetic Aperture Radar

${ }^{6}$ STRIPMAP: Map of Image Separation Formed by the Width of the SAR Radar Bar.

${ }^{7}$ OACI: Organización de Aviación Civil Internacional (International Civil Aviation Organization).

${ }^{8}$ ITU: International Telecommunications Unit.

${ }^{9}$ GIDENUTAS: Grupo de Investigación de Nuevas Tecnologías de Aplicación Social, Universidad Distrital Francisco José de Caldas sede Tecnológica. Investigation Group of New Technologies of Social Application of the Universidad Distrital Francisco José de Caldas Technology Headquarters. 
European inventors such as George Cayley (English Mathematician) in 1809, Félix du Temple (From the French Navy), in 1857 [1].

Towards 1864, James Maxwell described the laws of electromagnetism. A few decades later, around 1887, Heinrich Hertz experimented with radio waves in Germany, finding that while these waves could be transmitted by some materials then were reflected in other materials, for example Metal Surfaces [2]. But as such, UAVs will incorporate sensors such as radar into the twentieth century. UAVs began incorporating recognition sensors to promote the use of satellites [3]. In 1991, the US used target drones named Chukar as decoys during the Gulf War [4]. In 1994 the first flight of the "Predator" was made: it is the first operating UAV using GPS global positioning system instead of being programmed or to use the line of sight, because it is more reliable, making use of itself the following year in the Yugoslavian war [5]. In 1998 the Global Hawk was developed, an UAV that reaches an altitude of 18.3 kilometers and was designed to stay in the air a while $\max 32$ hours in an enemy territory [6].

For the twenty-first century, in 2001, the first flight was made by a MQ-9 Reaper, (Originally baptized as Predator-B). horsepower motor. The Reaper is an unmanned aircraft turboprop that has 950 a Its production started the following year [7]. In 2007 Electro-optical sensors (EO) were developed for UAVs which it is capable of recording electromagnetic radiation in the visible spectrum. These tolerate the capture of both still images and videos with the development of artificial vision techniques [8]. In 2008 the SAR UAVs were incorporated, which provide high-resolution images (all the time) in an area of $9.8 \mathrm{Sq}$. KM. The SAR is currently being used successfully in the compilation of terrain profile, mining, and oil slicks monitoring [9].

Towards 2010, the Laser-Radar sensor is incorporated (LADAR) for UAVs which allows the acquisition of three-dimensional information of the scenes. It can penetrate through a cover like vegetation or camouflage [10]. Meanwhile, by the year 2013 the detector or sensor for nuclear, chemical, biological, and radiological explosives was incorporated (CBRNE). Also smaller, lighter and more sensitive sensors were developed by allowing CBRN as an application in UAVs, towards security applications [11]. Today Signal Monitoring Sensors are still being developed.

(SIGINT- Signal Intelligence), this allows the detection, identification, geolocation and copy of the radio signals of the environment, allowing intelligence services of the security forces to know the capabilities, arrangements, compositions and intentions of the monitored elements [12]. In Figure 1, a timeline is shown for the development of UAVs by incorporating sensors:

Figure 1: Development UAVs technology [13].

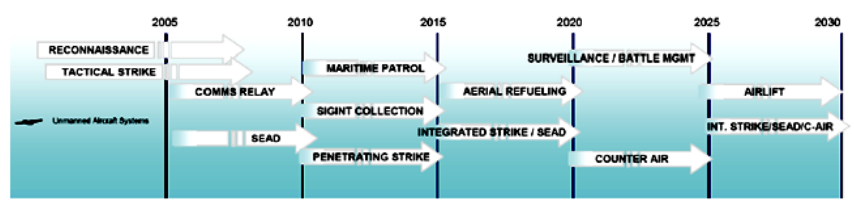

\subsection{Mathematical and Physical Model of RADAR}

In a UAV, the operation is explained from both mathematical and physical models. For example: the geometric modeling, static and of dynamic elements. Therefore, it is possible to take into account their real capacity during a flight. For the figure above, the following parameters were determined:

- Geometry, stability and control

- Euler Model

- The Newton Method

In [14] as it is described in detail the above elements.

Now, in terms of RADAR, it shows that the electromagnetic system is used for detecting and locating objects. For its modeling, it is cut from the transmission of some sort of a particular type of waves, for example a pulsated modulated sinus and the detecting nature of the echo signal.

\subsubsection{Band of Frequency Ka}

The Ka band covers a range of frequency from $27 \mathrm{GHz}$ ranging to $40 \mathrm{GHz}$. At the same time, the millimeter band covers the frequency range from 40 $\mathrm{GHz}$ to $300 \mathrm{GHz}$. The International Telecommunications Unión (ITU) assigns the frequency range of 33.4 to 36 $\mathrm{GHz}$ for radar applications in the $\mathrm{Ka}$ band, while in the lower region of the millimetric bands the assigned bands are from $64 \mathrm{GHz}$ to 59,76 to $81 \mathrm{GHz}$ and 92 to $100 \mathrm{GHz}$ [15]. It is of multiple interests what the RADAR has to offer for the social sector. In the civil field, the miniaturization of sensors and their use in medium-short distance is permitted. In the military

\footnotetext{
${ }^{10}$ LPI: Low Probability of Interception allows to hide the presence of the sensor, emitting low power.
} 
field, the emissions are very difficult to detect (LPI $)^{10}$ for a possible far interception and difficult to interfere, because of countermeasures systems, if it is compared with emissions at longer wavelengths [16].

\subsubsection{Waveform FMCW}

The high resolution signal transmitted from a FMCW Radar consists of a continuous train of:

$$
S_{t x}(t)=\sqrt{2 \cdot P_{t} \cdot Z_{0}} \cdot \operatorname{rect}\left(\frac{t}{T}\right) \cdot \operatorname{sen}\left(\omega_{0} t+\pi \frac{B}{T} t^{2}\right)
$$

Where $\omega_{0}$ is the central pulsation scan, hereinafter refers to carrier of the pulsation system. $B$ is the width of the scanned band, $T$ is the scanned time, and $P_{t}$ is the measured power transmitted over the impedance reference $Z_{0}$, and the rect function is defined by (2)

$$
\operatorname{rect}(x)= \begin{cases}1 & |x| \leq \frac{1}{2} \\ 0 & o c\end{cases}
$$

The received signal from a target located at a distance of the RADAR $R_{t}$, is an attenuated and delayed version of the transmitted signal:

$$
\begin{array}{r}
S_{r x}(t)=\sqrt{2 \cdot P_{r} \cdot Z_{0}} \cdot \operatorname{rect}\left(\frac{t-t_{R}}{T}\right) . \\
\operatorname{sen}\left(\omega_{0}\left(t-t_{R}\right)+\pi \frac{B}{T}\left(t-t_{R}\right)^{2}\right)
\end{array}
$$

Where $P_{r}$ represents the power received by the radar from the target, and $t_{R}$ represents the round trip delay suffered when the wave travels from Target to Radar:

$$
t_{R}=\frac{2 R_{t}}{c}
$$

Where $c$ is the speed of wave propagating in the middle. If you think about the implementation of a mixer-based receiver [17], the received signal is mixed with the original transmitted signal, obtaining the so-called scanned signal:

$$
\begin{array}{r}
S_{t x}(t) \times S_{r t}(t)=K \cdot \sqrt{\sigma} \cdot \operatorname{rect}\left(\frac{t-t_{R}}{T-t_{R}}\right) . \\
\cos \left(2 \pi t_{R} \frac{B}{T} t+\Phi_{1}\right)- \\
K \cdot \sqrt{\sigma} \cdot \operatorname{rect}\left(\frac{t-t_{R}}{T-t_{R}}\right) \cdot \cos \left(2 \omega_{0} t+\Phi_{2}(t)\right)
\end{array}
$$

Like any limited energy signal has Fourier transform; if the scanned signal of a target during infinite time is received, its Fourier transform spectral delta would be of zero width. But nevertheless, every scanned signal is received only for a while $T$ (supposing that $T>t_{R}$ ) period lasting emission and reception of each ramp. The Fourier transform of the rectangular window is the sync signal equation:

$\operatorname{rect}\left(\frac{t}{T}\right)=\left\{\begin{array}{ll}1 & -\frac{T}{2} \leq t \leq \frac{T}{2} \\ 0 & \text { resto }\end{array} \Rightarrow \operatorname{sinc}(f)=\frac{\operatorname{sen}(\pi T f)}{\pi f}\right.$

When performing the Fourier transform of the signal and appealing to the property of modulating of such said transform, each delta spectrum, theoretically zero width, It is going to become a SINC, with a main lobe width $2 / T$ [18]. The width of the main lobe of the sync at $3 \mathrm{~dB}$ to the maximum is about $1 / T$. Making use of the expression (7), it shows that the resolution at a distance of the system at $3 \mathrm{~dB}$ is inversely proportional to the bandwidth transmitted:

$$
\Delta f=\frac{1}{T} \rightarrow \Delta r=\frac{c}{2 B}
$$

Furthermore, the Doppler frequency induced by a moving target can be measured through the phase change that experiences the scanning signal of that target along a series of ramps [19].

$$
\Phi_{l}(\hat{t})=\omega_{0} t_{R}(\hat{t})-\pi t_{R}^{2}(\hat{t}) \cdot \frac{B}{T} \approx \frac{4 \pi}{\lambda} \nu_{r} \hat{t}+\frac{4 \pi}{\lambda} R_{i n i}
$$

The Doppler resolution is given by the inverse of the lighting time, due to the property of the Fourier transform. Knowing the repeated interval ramps, $P R I$, and the number of ramps, $N$, used to determine the Doppler frequency, leads to the expression that determines the Doppler resolution:

$$
\Delta f_{D}=\frac{1}{N \cdot P R I}
$$

It is important to realize how you are getting the Doppler history of the target sampled, with a sampling frequency $P R F=1 / P R I$. Therefore, the maximum Doppler frequency that can be measured unambiguously and it is determined by direct application of the Nyquist criterion [20].

$$
\left|f_{D \max }\right| \leq \frac{P R F}{2}
$$




\subsection{UAV with RADAR (UAVSAR) Functioning Model}

Table 1. Illustrates the technical features and the aid of the sensors for this type of aircraft.

Table 1: Types of UAVs [21].

\begin{tabular}{|c|c|c|c|c|c|c|}
\hline Type & $\begin{array}{l}\text { Max. Height of } \\
\text { Flight }\end{array}$ & $\begin{array}{l}\text { Max. Distance of } \\
\text { Operation }\end{array}$ & $\begin{array}{l}\text { Carrying } \\
\text { Capacity }\end{array}$ & $\begin{array}{l}\text { Typical } \\
\text { Sensors }\end{array}$ & $\begin{array}{l}\text { Additional } \\
\text { Comments }\end{array}$ & Example \\
\hline Micro- UAV & $600 \mathrm{~m}$ & $2 \mathrm{Km}$ & $<1 \mathrm{Kg}$ & $\begin{array}{c}\text { Small videocamera } \\
\text { and or IR }\end{array}$ & $\begin{array}{c}\text { Transported and } \\
\text { Launched by hand } \\
\text { flight duration } 1 \text { hour }\end{array}$ & Aladin (Germany) \\
\hline Mini- UAV & $2 \mathrm{Km}$ & $10 \mathrm{Km}$ & $<10 \mathrm{Kg}$ & $\begin{array}{c}\text { Videocamera } \\
\text { and or IR }\end{array}$ & $\begin{array}{c}\text { Also denominated UAV } \\
\text { of approximate length } \\
\text { of flight }+-1 \text { hour }\end{array}$ & Bird Eye (Israel) \\
\hline Short Distance & $4,5 \mathrm{Km}$ & $50-150 \mathrm{Km}$ & $<100 \mathrm{Kg}$ & $\begin{array}{c}\text { Video Cámara, } \\
\text { IR, Radar, ELINT }\end{array}$ & $\begin{array}{l}\text { Also Denominated type } \\
\text { OTAN, or UAV tactic }\end{array}$ & Sperwer (France) \\
\hline Mid Distance & $6 \mathrm{Km}$ & $200 \mathrm{Km}$ & $<150 \mathrm{Kg}$ & $\begin{array}{c}\text { VideoCamera, } \\
\text { IR, Radar, ELINT }\end{array}$ & & Hermes 450 (Israel) \\
\hline MALE & $10 \mathrm{Km}$ & $200 \mathrm{Km}$ & $<300 \mathrm{Kg}$ & $\begin{array}{c}\text { VideoCamera, } \\
\text { IR, Radar, ELINT }\end{array}$ & $\begin{array}{l}\text { Medium Altitude, Long } \\
\text { Endurance } \\
\text { Dozens of hours of flight } \\
\text { length of time }\end{array}$ & Predator (USA) \\
\hline HALE & $>10 \mathrm{Km}$ & $>1000 \mathrm{Km}$ & $>300 \mathrm{Kg}$ & $\begin{array}{c}\text { VideoCamera, } \\
\text { IR, Radar, ELINT }\end{array}$ & $\begin{array}{c}\text { High Altitude, Long } \\
\text { Endurance } \\
\text { Dozens of hours of flight } \\
\text { length of time }\end{array}$ & Global Hawk (USA) \\
\hline
\end{tabular}

The synthetic aperture radar systems (SAR) are able to obtain two-dimensional images of the terrain through the transmission and reception of electromagnetic signals in spaced positioning describing an ideal trajectory, for them there must achieve a high resolution in the two-dimensional image.

First, to achieve high resolution in the perpendicular direction to the path, a named distance or slant range, there needs to be able to transmit signals with high bandwidth. Secondly, to achieve high resolution in the direction parallel to the path, named azimuth or cross range, it should decrease the wavelength so that the emission point is more directive [22].

\subsubsection{Environment Simulations SAR in STRIPMAP Mode}

To simulate the scene, it is necessary to model the StripMap geometry. The StripMap mode consists of a radar antenna, placed at a squint angle, moving in a straight line and pointing to the scene without changing the pointing angle throughout the observation time. The azimuthal resolution achieved by this mode of operation is limited by the width of the actual antenna beam: The greater it is, the greater can be the synthesized array and, therefore, the better the azimuthal resolution. The length of the band scanned is limited by the distance flown by the UAV described in Figure 2 shows the geometry StripMap.

Figure 2: Definition of SAR geometry SAR for Strimp SOLAR mode [23].

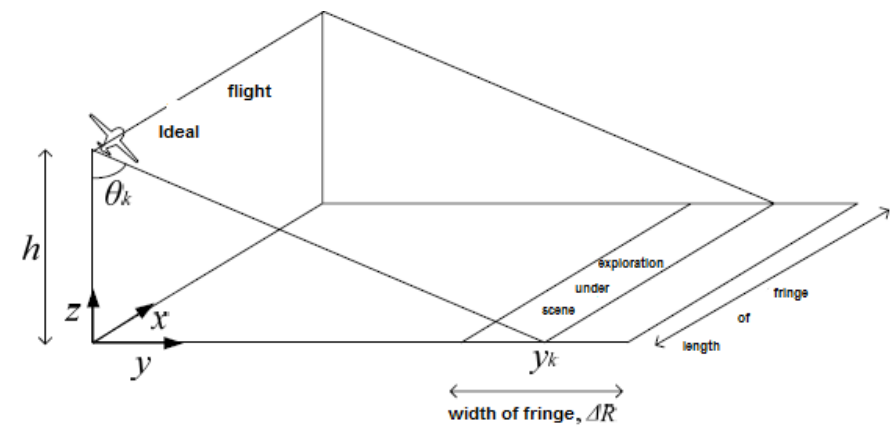

To understand the methodology of the implemented simulation, you must start by explaining the model of radar signal. The signal transmitted by a FMCW radar is a continuous train of frequency ramp forms [24].

$$
S_{t x}(t)=\sqrt{P_{t} Z_{0}} \cdot \operatorname{rect}\left(\frac{t}{T}\right) \exp \left(i 2 \pi f_{0} t+j \pi \gamma t^{2}\right)
$$

Where $f_{0}$ is the central frequency of the scan, and represents the frequency scan rate of the modulation, $P_{t}$ 
is the transmitted power measured over the reference of impedance $Z_{0}$.

\subsubsection{Point Targets}

A point target is modeled with its position in the scene and its radar section. It is assumed that the size of the target is less than the resolution cell, that is why geometrically it is modeled as a simple point where the transmitted signal is reflected, there is where the name point comes from:

$$
P_{t}(m)=\frac{P_{t} G_{a}^{2}(m) \lambda^{2}}{(4 \pi)^{3} R^{4}(m)} \sigma(m)
$$

Where $G_{a}(m)$ It is the antenna gain for the $m$ ramp, (Assuming a homeostatic system), $R(m)$ is the distance between the target and the radar on the $\mathrm{m}$ ramp. $\sigma(m)$ is the targets radar section, and $\lambda$ is the waves longitude.

\subsubsection{Extensive Targets.}

In the case of the extensive targets, the modeling needs to combine two different models, one geometric and the other electromagnetic. The combination of both models allow the simulation of an extensive target, which will allow to calculate the radar section of any large target from the contributions of each one of the facets that form. [25].

\subsubsection{UAV influence movement in SAR image formation.}

Synthetic aperture radar in Strip Map mode needs to describe in a perfectly straight line and at constant speed. This is so that it can transmit and receive signals in the predefined positions for the flight plan. That is why the emission of each ramp must be perfectly synchronized with the speed of the aircraft, so that the signals are received in equispaced positions [26].

Movement errors can be classified into movement errors inter- ramp (ramp to ramp) and movement errors Intra-Ramp (inside the ramp) [27].

\subsubsection{Inertial and or Navigation Systems.}

Most of the SAR systems have an integrated motion measurement unit (IMU / INS: (Inertial Measuring Unit/Inertial Navigation System), which contains the motion sensors of the entire system. Depending on the measurements of these sensors, they must be estimated and the motion errors corrected, so that it can ensure the quality of a SAR product. For proper operation of the
SAR system, there should ensure that the IMU installed on the antenna has sensors with sufficient bandwidth to measure the actual path. In addition, the measurement uncertainty should be small enough to point out minor error movements than the wavelength of the SAR $[28,29]$.

\subsection{Rules and Policies.}

To make the flight of an aircraft piloted by a safe remote control, standard rules have been established by national and international authorities as well as ensuring national air operations to minimize the risks to people involved with the activity can be exposed to [30].

In the international context we have the International Civil Aviation Organization (OACI) created by the Chicago Convention on December 12, 1944 and which Colombia takes part in. The organization is responsible for developing standards and methods for civil aviation according to Circular 328 was published in 2011, (ICAO 328-AN / 190). Unmanned Aircraft Systems (UAS) in order to provide guidance on concepts and terms to the flight of an aircraft, there are three purposes for this standard: First. Having known the position of the agencies on the use of UAS. Second. To report on the differences between manned aviation and the UAS [31]. Third. Encouraging states to integrate and contribute to the development of regulation based on experiences related to the UAS of each. In Colombia the Civil Aviation created under the Regulatory Circular No. 002 of 2015 which established the general requirements for airworthiness and operations RPAS (Remotely Piloted Aircraft Systems) including different purposes than recreational and sports ones. It is determined by a number of provisions and requirements for operators of such equipment [32]. Among the most important points are that the maximum weight allowed for each RPA is 25 kilograms, (heavier civilian operation would be prohibited), which must be equipped with autopilot and has GPS [33]. Whoever manipulates this type of aircraft, must have a minimum of 40 hours flight time and 200 takeoffs and landings, which can be certified by training centers supported by Civil Aeronautics. In regulating the use of UAS is not always forbidden to take aerial photograph as long as the standards are respected [34]. The Radio communication sector is to ensure the rational, equitable, efficient and economical use of the radio frequency spectrum by all radio communication services.

It is considered that several bands of millimeter waves are intended for unmanned vehicle radars. The Federal Communications Commission (FCC) of the United States and the Ministry of Internal Affairs and 
Communications of Japan (MIC) have assigned $76 \mathrm{GHz}$ band for this particular purpose [35].

\subsection{Civil Applications:}

\subsubsection{Natural Disasters:}

One of the most used applications for the civilian population is one that helps rescuers in situations of natural disaster, provided an opportunity to get to places where people have limitations [36]. Where technological development is a vital tool in detecting, to locate and to rescue victims of natural disasters such as avalanches and earthquakes. In Figure 3. the detection of this type of RADAR and UAV systems are shown [37].

Figure 3: Search of missing persons during the use of UAS [38].

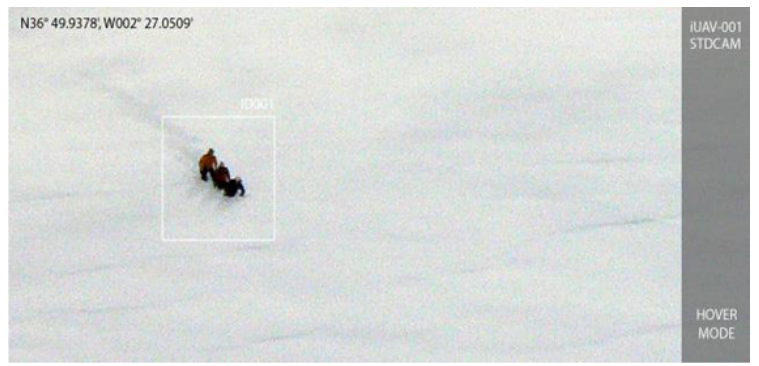

\subsubsection{Prevention and control of fires}

There is a development of a high fidelity processor aboard a UAVSAR that collects information to generate appropriate images by giving rapid response to natural disasters such as the eruption of a volcano, earthquakes, forest fires, landslides and floods [39, 40]. With this application, there is an approximately disaster performing analysis presented with intervals of hours and days. The goal is to generate high fidelity and accuracy in a disaster and timely nalysis of the data needed to respond. In Figure 4. the analysis to these situations is shown [41].

Figure 4: Fire control during the use of UAS [42].

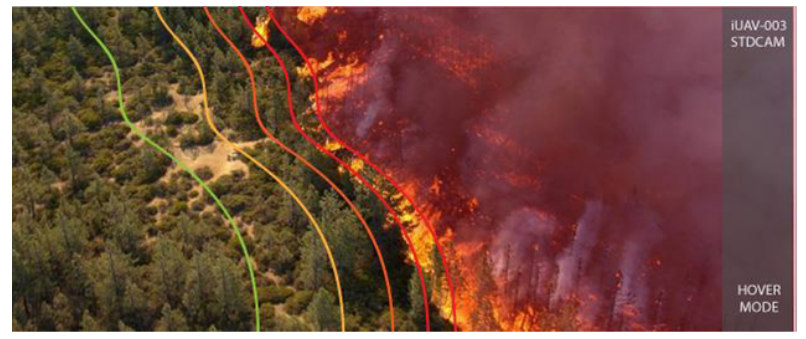

\footnotetext{
${ }^{11}$ MTI: Indicator of Mobile Targets
}

\subsubsection{Georeferencing:}

As part of the policy "State Land Restitution" led by the government of Juan Manuel Santos, the Instituto Geográfico Agustín Codazzi (IGAC) ventures into the use of new technologies that permit to speed up the required mapping process for the proper development. The IGAC, is the official pioneer entity with the use of drones that have a georeferencing purpose and a generation of mapping.

There are more than 42 areas in the departments of Magdalena, Bolivar, Sucre, Cesar, Tolima, Valle Del Cauca, Caldas, Cundinamarca and Meta, where this technology is used. These areas were prioritized due to cadaster and land restitution being carried out [43].

\subsubsection{Pseudo Satellites:}

The high cost associated with putting into orbit a payload makes some alternative to satellites very tempting. Regarding this issue, UAVs are used as Pseudo satellites capable of performing the same tasks of monitoring and communications [44].

\subsection{Military Applications:}

Military applications are innumerable [45]. Here is a summary of them, and without being a long process, it will provide an overview of the potential of the radar-UAV combination.

\subsubsection{Reconnaissance and surveillance:}

The main military application is in missions of reconnaissance and surveillance. The advantages are many: The system can operate both night and day, in adverse weather conditions and poor visibility, where IR sensors and visible cameras stop working. By using SAR techniques, space-time adaptive processing (STAP), $\mathrm{MTI}^{11}$, interferometry, (InSAR), polarimetry and / or tomography, information can be extracted from the state of infrastructure and terrain, as well as locating targets [46].

\subsubsection{Map Extraction:}

As in the case of civilian applications, there can be two-dimensional and three-dimensional maps drawn, classifying land and vegetation information. All this information is very valuable when planning a mission [47]. 


\subsubsection{Maritime Control:}

As in the case of civilian applications, radar systems can be used to control the maritime environment. In addition to the already cited in the civil case, it is possible to obtain ISAR images, and InSAR of ships, warships and submarines, to attempt their classification (Friendly-Enemy), and if it is probable, its identification [48].

\subsubsection{Meteorology:}

Weather information can also be used for mission planning. It is useful in calculating the pointing and scope of the artillery, avoiding collateral damage associated to error shooting accuracy [49].

\subsubsection{Furtive Penetration:}

Tactical observation UAVs are of small size, small radar signature and are quite silent, which makes them ideal for tasks stealthy infiltration [50].

\section{Conclusions:}

The low economic cost compared with manned aircraft and reduced detectability of the same ones. Not having to host a pilot inside is reduced by $50 \%$ over the cost of a manned aircraft, allowing a smaller design. In addition, the formation of experienced pilots is avoided, it also reduces maintenance.

Within the context of radars on board UAV, a desirable feature is that the system can be miniaturized as much as possible, because these platforms usually have Payload limitations on board, radar sensors are needed with good features for resolution, sensitivity and scope.

Designs with a single antenna get a significantly reduction of the size and weight of the system facilitating a possible installation on board a UAV [51].

The implementation of synthetic systems aperture radar in a UAV greatly facilitates data collection and images of high fidelity, additionally, accuracy to detect and avoid natural disasters thus saving thousands of lives.

That easiness is due to the capacity of electromagnetic waves to traverse certain obstacles, such as building materials, land, vegetation, which allow the opening of applications, as intrusion detection through walls, detection of buried survivors, buried mine detection, detection of enemy troops camouflaged.

\section{Acknowledgements}

The GIDENUTAS group and the SCIBAS group, those assigned to the Research Center and scientific development CIDC of the UDFJ de C (Universidad Distrital Francisco Jose de Caldas) and to those for the theoretical and technical support.

\section{References}

[1] Librosmaravillosos.com "La Historia de la Aviación - Revista Sucesos", january 27 th 2016. [Online]. Available: http://www.librosmaravillosos.com/ lahistoriadelaaviacion/capitulo06.html

[2] I. A. Fernández. "El radar durante la II Guerra Mundial", july 11 th 2016. [Online]. Available: http://histinf .blogs . upv.es/files/2011/12/ radar.pdf

[3] C. M. Richard. "Uninhabited Combat Aerial Vehicles: Airpower by the People, for the People, But Not with the People", july 11 th 2016. [Online]. Available: http://www.jhuapl.edu/techdigest/ TD/td3203/32_03-Keane.pdf

[4] N. C. Bernard. "Winged Shield, Winged Sword: A History of the USAF, Air Force History and Museums Program", july 11 th 2016 [Online]. Available: http://www . afhso.af.mil/shared/ media/document/AFD-101006-029.pdf

[5] O. R. Thomas. "Uninhabited Air Vehicle Critical Leverage System for Our Nation's Defense in 2025", july 11 th 2016 [Online]. Available: http://www . jhuapl . edu/techdigest/TD/td3203/ 32_03-issue.pdf

[6] S. N. Lloyd. "Naval Consulting Board of the United States, Government Printing Office, Washington, DC, 1920", july 12 th 2016 [Online]. Available: http: //edison.rutgers.edu/Scott.pdf

[7] C. J. Robert. "The Official Chronology of the U.S. Navy in World War II, U.S. Naval Institute, Annapolis", july 11 th 2011 [Online]. Available: https://books.google.com.co/books?id= NkGNAgAAQBAJ\&pg

[8] N. B. Geddes. "Magic Motorways. Random House Book, New York, NY, USA. 1940", july 11 th 2016 [Online], Available: https://archive.org/ details/magicmotorways00geddrich

[9] B. R. Dickmanns. "the seeing passenger car 'VaMoRs-P', Proceedings of the Intelligent Vehicles '94 Symposium, 1994", july 11 th 2016 [Online], 
Available: https://books.google.com.co/books? id=9jp_pjLQDMkC\&pg

[10] W. Douglas. "A Question of Loyalty: Gen. Billy Mitchell and the Court-Martial That Gripped a Nation", july 11 th 2016 [Online], Available: http://www.au.af.mil/au/afri/aspj/ airchronicles/bookrev/waller.html

[11] D. Martínez. "Cooperation between UAS and Wireless Sensor networks for efficient data collection in large environments". J. Intell Robot Syst, vol. 70, 2013, pp. 491-508.

[12] M. S. "Validation of measurements of land plot area using UAV imagery". International Journal of Applied Earth Observation and Geoinformation, vol. 33, 2014, pp. 270-279. https://doi.org/10.1016/ $\mathrm{j} \cdot \mathrm{jag} \cdot 2014.06 .009$

[13] W. Zang. 'Investigating small-scale water pollutionwith UAV remote Sensing technology". july 11 th 2016 [Online] Available: http://ieeexplore. ieee.org/abstract/document/6321515/

[14] R. Tapia, P.Rosa, B. F. Sánchez, "Drones: general aspects and social applications". Revista Vision Electronica, vol 10, no 2, july-december 2016.

[15] IEEE Std 521-2002, "Std 521 - 2002", july 11 th 2016 [Online], Available: http://ieeexplore.ieee. org/stamp/stamp. jsp?arnumber $=1160089$

[16] G. P. Kulemin "Millimeter-wave radar targets and clutter". USA: Artech House, MA, 2003.

[17] J. I. Scheer, "Coherent Radar Performance Estimation" Norwood: Artech House, 1993.

[18] A. W. Schafer. "Discrete-Time Signal Processing", New Jersey: Prentice Hall, Engewood Cliffs, 1989.

[19] R. M. Majewski. "Spotlight Synthetic Aperture Radar: Signal Processing Algorithms". London: Artech House, 1995.

[20] L. N. Mozeson. "Radar Signals", New Jersey: Wiley-Interscience, 2004.

[21] S. A. Cambone, K. J. Krieg, P. Pace, L. Wells, "Unmanned Aircraft Systems (UAS) Roadmap, 2005-2030". Department of Defense, United States of America, july 14 th 2016 2005. [Online], Available: http://fas.org/irp/program/collect/ uav_roadmap2005.pdf

[22] M. Soumekh. "Synthetic Aperture Radar Signal Processing with MATLAB Algorithms". USA: John Wiley \& Sons, Inc, 1999.
[23] W. L. Post. "Line of Sight Considerations in the Fulda Gap Area of the Federal Republic of Germany."Technical Report DELCS-TR-82-2. U.S. Army ERADCOM Combat Surveillance \& Target Acquisition Laboratory. Fort Monmouth, july 11 th 2016 [Online], Available: https: //www.ll.mit.edu/publications/journal/pdf/ vol03_no1/3.1.6.radaraUAV.pdf

[24] R. S. Goodman "Radar: Signal Processing Algorithms". London: Artech House, 1995.

[25] J. T. Castillo. "Modelado de Blancos Extensos para la Simulación de Escenarios en Radares de Apertura Sintética". XX Simposium Nacional de la Unión Científica de Radio (URSI 2005), Valencia, Spain, September 2005.

[26] E. C. Zaugg. "Full motion compensation for LFM-CW Synthetic Aperture Radar". International Geoscience and Remote Sensing Symposium, IGARSS 2007, pp. 5198 - 5201, 23-28 July 2007. https://doi.org/10.1109/IGARSS . 2007.4424033

[27] L. G. David. "Theory and application of motion compensation LFM-CW SAR". Trans. Geoscience and Remote Sensing, vol. 46, no. 10, october 2008, pp. 2990 - 2998. https://doi.org/10.1109/TGRS. 2008.921958

[28] T. A. Kennedy. "Strapdown Inertial Measurements Units for Motion Compensation for SAR". Aerospace and Electronics Systems Magazine, vol. 3, no.10, october 1988.

[29] J. C. Kirk. Electronic "Motion Compensation for synthetic aperture radar", Trans. Aerospace and Systems, vol. AES-11, no. 3, may 1975, pp. 338-348. https://doi.org/10.1109/TAES.1975.308083

[30] J. Ontiveros. "Controlador aéreo. Aeronaves no tripuladas y control del tráfico aéreo". july 15 th 2016 [Online]. Available: http://www.hispaviacion.es/ author/jorgeontiveros/

[31] OACI. "Sistemas de aeronaves no tripuladas (UAS), 2011". july 15 th 2016 [Online]. Available: http://www.icao.int/Meetings/UAS/Documents/ Circular\%20328_es.pdf

[32] UAS. "Sistemas de aeronaves no tripuladas", july 16 th 2016 [Online]. Available: http: //www.icao.int/Meetings/UAS/Documents/ Circular\%20328_es.pdf

[33] Á. M. Pardo "Aeronaves de Combate No Tripuladas (UCAV) Unmanned Combat Air Vehicle, Velocirraptor", july 11 th 2016 [Online]. Available: 
http://www.militar.org.ua/militar/aviacion/ avion-Unmanned-Combat-Air-Vehicle.html

[34] UAV task-force, "final report, and a concept for European regulations for civil unmanned aerial vehicles (UAVs)", july 11 th 2016 [Online]. Available: http://www.eurousc.com/media/1054/ npa_16_2005_appendix.pdf

[35] Recomendación ITU-R M.1452-1 (10/2009). july 11 th 2016 [Online]. Available: https://www.google. com. co/webhp? sourceid=chrome-instant\&ion $=1 \&$ espv $=2 \&$ ie $=U T F-8 \# q=$ Recomendaci $\% C 3 \% B 3 n+I T U-R+$ M. $1452-1+(10 \% 2$ F 2009$)$

[36] Ministerio de Defensa. "UAS (Unmanned Aircraft System. Sobre su integración en el espacio aéreo no segregado". Monografías del SOPT, july 11 th 2016 [Online]. Available: http://www.tecnologiaeinnovacion.defensa. gob.es/Lists/Publicaciones/Attachments/18/ monografia_sopt_1.pdf

[37] "Cronología de los UAV". july 11 th 2016 [Online]. Available: http:// actualidad.rt.com/actualidad/view/ 80396-vehiculos-aereos-tripulados-hitos-histol ricos

[38] C. Kopp. "Active Electronically Steered Arrays," Air Power Australia website, 2007. Retrieved May 30, august 18 th 2016 [Online]. Available: http: //www ausairpower.net/aesa-intro.html

[39] R. Austin. "Unmanned Aircraft Systems: UAVS Design, Development and Deplyment", 2010. WILEY. july 11 th 2016 [Online] Available: http://airspot.ru/book/file/1152/Reg_ Austin_-_Unmanned_Air_Systems_UAV_Design_ _Development_and_Deployment___2010.pdf

[40] V. Raska. "See and Avoid (SAA) Passive Ranging Concepts," Proceedings of TAAC Conference, Santa Ana Pueblo, New México, august 20 th 2016 [Online]. Available: https: //repositorio.unican.es/xmlui/bitstream/ handle/10902/3838/359538. pdf? sequence=1

[41] D. E. Grilley. "Resolution Requirements for Passive Sense \& Avoid," Alion Science \& Technology, 3592 Collins Ferry Rd., Ste. 180, West Virginia: Morgantown, 2005.

[42] D. J. Kim. "Hierarchical Longitudinal Controller for Rear-End Collision Avoidance". Transactions on Industrial Electronics, vol. 54, no. 2. 2007.
[43] Igac, "Drones y Radares: Tecnologías del IGAC para apoyar el proceso de restitución de tierras", august 20 th 2016 [Online]. Available: http://www.igac.gov.co/wps/wcm/connect/ e313c30042359f45b9c9fda2b03bb2df/Drones+y+ radares . pdf?MOD=AJPERES

[44] "Competitive speciation and costs of choosiness", august 20 th 2016 [Online]. Available: http://onlinelibrary.wiley.com/doi/10.1111/ j.1420-9101.2008.01547.x/full

[45] P. Pace. "Unmanned Aircraft Systems (UAS) Roadmap, 2005-2030". Department of Defense, United States of America, august 20 th 2016 [Online]. Available: http://www.tc.faa.gov/its/worldpac/ techrpt/ar0841.pdf

[46] S. Zhishun. "Detecting the strong scatterers of target with ISAR". Proceedings of the Aerospace and Electronics Conference, NAECON, vol. 2, May 1995, pp. 992 - 995, 22-26. https://doi.org/10.1109/ NAECON . 1995. 522059

[47] W. L. Post. "Line of Sight Considerations in the Fulda Gap Area of the Federal Republic of Germany."Technical Report DELCS-TR-82-2. U.S. Army ERADCOM Combat Surveillance \& Target Acquisition Laboratory. Fort Monmouth, august 20 th 2016. [Online]. Available: https: //digital.lib.washington.edu/researchworks/ bitstream/handle/1773/26779/Oglesby_ washington_02500_13224.pdf?sequence=1

[48] M. Weisgerber, "USAF Seeks Endurance-Payload Sweet Spot," august 20 th 2016 [Online]. Available: http://www.dis.xlibx.info/dd-other/ 418924-11-congressional-research-service-7-\ 5700-wwwcrsgov-r42136-crs-report.php

[49] A. Gonzalez. "Radar Sensor in Millimeter-Wave Band". International Conference on Sensor Technologies and Applications, Sensor Comm 2007, pp. $5-9$, 14-20, Oct. 2007.

[50] H. Chao. "Remote Sensing and Actuation Using Unmanned Vehicles". august 20 th 2016 [Online]. Available: http://onlinelibrary.wiley.com/doi/ 10.1002/9781118377178.fmatter/pdf

[51] M. Datcu. "Corregistro de Imágenes SAR basado en diferentes Estimadores de Coherencia". XXIII Simposium Nacional de la Unión Científica de Radio (URSI 2008), Madrid, Spain, pp. 22-24, September 2008. 